\title{
Studies on the Comparative Toxicity of Jathropha curcas and Synthetic Nematicide on the Root-Knot Nematode Infected Sweet Pepper (Capsicum Annuum)
}

\author{
Hinmikaiye, A.S., ${ }^{1}$ Abolusoro, S.A.,Oloniruha, J.A., ${ }^{*}$ Ogundare, S.K.,Babalola, \\ T.S.,Kadiri, W.O.J, Ayodele, F.G \\ College of Agriculture, Division of Agricultural Colleges, Ahmadu Bello University Zaria, Nigeria \\ Department of Crop science Landmark University, crop science, Omu-Aran \\ stevabolusoro2005@yahoo.co.uk
}

Abstract: The efficacy of carbofuran and plant extracts from Jartrophacurcas in the control of root knot nematode, Meloidogynesppwas investigated in screen house experiments using potted plants. The carbofuran, a synthetic nematicide was applied at the rate of $3 \mathrm{~kg}$ ai $/ \mathrm{ha}(0.5 \mathrm{~g} / \mathrm{stand})$.

The plant powder material were applied as soil amendment and was incorporated into the soil at the rate of 5 tons/ha (25g per stand). While the test plant liquid extracts were applied to the soil at the rate of $30 \mathrm{ml} \mathrm{per} \mathrm{pot.}$ Also the test plant ethanoic-extract was applied to the soil at the rate $30 \mathrm{ml}$ per pot. There were also untreated controls which serve as standard check.

The experiment was carried out as a 5 × 2 x 5 factorial experiment fitted into Randomized Complete Block Design. The results showed that the plant materials used in this study was effective to different extents against the target nematode Meloidogynespp. as it reduced the incidence and adverse effects on the growth and yield performance of sweet pepper Capsicum annum. All the measured parameters except root gall rating were significantly higher for treated plant than for untreated ones (i.e control).

The result further showed that the treatments had significant effect on number of leaves, plant height, number of branches, days to $50 \%$ plant flowering, shoot weight, root weight, fruit weight, number of fruit/pot and gall indices compared to untreated control plant. The roots of the treated plants were significantly less galled than those of the control.

Phytochemical screening showed that the plant materials contained carbohydrate, steroids, alkaloids, flavonoid and saponins which are known to be effectively lethal to most micro-organisms, nematode inclusive.

Keywords: Leaf extract,Jatrophacurcas, Synthetic nematicide, root-knot nematode andCapsicum annuum

\section{INTRODUCTION}

Vegetables have been rightly described as plants which provide a source of food often low in calories and dry matter content which are consumed in addition to a starchy basic food in order to make it more palatable (Grubben, 1977). They are, therefore, important food supplement in human nutrition being cheap sources of mineral vitamins and to some extent protein (Oke, 1996; Oyenugaand Fetuga, 1997; Omueti, 1980).

The essential calcium content contained in milk can be supplied through vegetables. Green vegetables are good sources of iron, thiamine, riboflavin and nicotinic acid. Apart from biological values that could be obtained from vegetables, they are a good sources of income for the farmer who could afford to raise them especially during the dry season by watering or irrigation when the price per kilogram in the market will double that in the rainy season. 
Sweet pepper is botanically called Capsicum annum. It belongs to the family Solanaceae called night shade family. The plant is slightly woody and upright, growing from $60-120 \mathrm{~m}$ high depending on the variety. Sweet pepper is a perennial crop which is usually cultivated as annualbut with good management can produce for 2-4 years depending on the variety. Sweet pepper which is closely related to egg-plant an tomatoes is a shrub.

Sweet pepper was reported to have originated from tropical America and quickly disseminated to the other parts of tropics as far back as 1492 (FAO, 1984). Sweet pepper is widely grown in south Europe and southern United States, India, Thailand, Indonesia, Japan, Mexico, Uganda and the Sudan. (Heiger and Smith, 1973; FAO, 1984).

It has tap root system while the roots are moderately extensive. The main axils are erect, woody at the base and branched. The stem is smooth and does not bear hair as in tomatoes and egg plant. Leaves are variably alternative, simple pointed and ovate. They are usually carried on long petioles. All leaves are dark green color. Flowers are borne in clusters of 1 or more in the leaf axils. Fruit are indehiscent berries of variable shapes; the color may be bright, green, yellow, red or brown. The seeds of all types of Capsicum annum are flat.

Sweet pepper has numerous uses both domestic and industrial wise. The crop is grown or cultivated solely for its fruits. The fruit which is a pod-like berry is used for many purposes in many homes and industry. It could be used as a condiment in the soup and stew because of its fleshy pericap. The unripened fruit is used for vegetable salad preparation. Both the fruit and leaves are ingredients in the preparation for human veterinary medicine (Dalziel, 1948;Chiej, 1984). It is an important source of vitamin A and C.Especiallywhen eaten raw (Grubben, 1977; Allardice, 1993). Attempts to increase the cultivation of sweet pepper have met with pest and disease problems the affected plants were stunted and had chlorotic wilted leaves which curled down and resulted in large spindle shaped gall on the roots.

Other disease militating against the cultivation of sweet pepper are fungal diseases such as damping - off which is a disease of seedlings and occurs on the seeding table when the young plants are just beginning to grow damping - off is not common when seedlings are grown in inert media such as rock-wool, it is more common in soil based media. The disease is more common where greenhouse sanitation practices are poor (Howard et $\mathrm{al}, 1994$ ) or where growing condition i.e. soil temperature, water, etc are not optimal and the young plants are stressed. Other fungal diseases include pythium crown and root rot, fusarium stem and fruit rot, gray mold andpowdery mildew.

Sweet pepper is also attacked by virus diseases. Examples are pepper mild mottle virus (PMMV), tobacco mosaic virus (TMV), tomatoes spotted wilt virus (TSWV) (Howard et. al, 1994, Portree 1996).

In Nigeria, root knot nematodes reduce the yield of sweet pepper (Sasser and Frechman, 1987). The nematodes affect seed germination, seedling survival, plant growth and fruit yield (Nath and Singh, 1992). Although synthetic nematicides could be used to combat the menace of the nematodes on this important vegetable, they are not eco-friendly. Apart from the hazards and low biodegradability of synthetic nematicides in the ecosystem, their usage is curtailed by their exorbitant prices.

In respect of the above problems, the objectives of this research work are therefore

1. To access the growth and yield of root knot nematode infected sweet pepper C. annumtreated with plant and carbofuran.

2. To compare the performance of the plant material with carbofuran on the population reduction of nematode in the root of sweet pepper.

3. To determine the bioactive chemical components present in the test plant Jatrophacurcas. 


\section{Materials AND Methods}

This research was carried out in two phases. The first phase was biological screening of test plants and the second was phytochmical screening for bioactive agents responsible for their nematicidal effects. The biological screening was carried out at the crop pavilion of the department of Crop protection of the University of Ilorin, Ilorin.

The experiment was carried out as a $5 \times 2 \times 5$ factorial experiment fitted into a randomized complete block design. Phytochemical screening was carried out at the Chemistry Department of the University of Ilorin, Ilorin.

\section{Pre-Planting Operation}

\section{Soil Collection and Sterilization}

Sandy-loam soil was collected from a fallow farm behind the Faculty of Agriculture of the University of Ilorin, Ilorin. The soil was sieved with $2 \mathrm{~mm}$ mesh sieve to remove gravels, stones and debris. The soil was moistened with water and filled into a metal drum and heated twice at an interval of 12 hours, at $60^{\circ} \mathrm{C}$ for 4 hours according to Gautam and Goswami (2002). The soil was left to cool for 24 hours stirred for aeration and then packed into fifty (50) 10 litre perforated experimental buckets at the rate of $10 \mathrm{~kg} /$ pot. The pots were then placed on a concrete stand to avoid nematode or microbial reinfestation.

\section{Seed collection and planting}

The seeds of sweet pepper (var. California Wonder) were bought from Kogi State Agriculture Development Project (A.D.P) at Kabba the seeds were raised on a sterilized soil which was filled into nursery bowl. After four weeks of germination and establishment, the seedlings were transplanted into the experimental pots. After establishment, the plants were later thinned to one healthy stand per pot and watered lightly twice daily until the project was terminated.

\section{Sources of the Test Plants and Carbofuran (Furadan)}

The leaves of Jatrophacurcas were collected from University area of Ilorin Township. Furadan (3G) a brand of carbofuran was purchased at an agrochemical store in Ilorin town.

\section{Extraction of Test Plant}

The leaves of Jatropha were dried at room temperature. The dried leaves were ground into powdery from using grinding machine. One kg of the ground leaves was poured into an aspirator and soaked with 5 litres of distilled water for 3 days. The aspirator was shaken thoroughly to allow the distilled water to circulate through the ground leaves.

The aqueous leaf suspension was later filtered, allowed to settle and filtered again using white muslin cloth and sieve to obtain a clear aqueous solution. The aqueous extract obtained was stored. Five hundred grammes (500g) of Jatropha leaf powder was poured into an aspirator and soaked in 2 litres of ethanol for 3 days. Thereafter, the ethanol suspension was filtered to get a clear crude extract. The ethanol extract, was allowed to undergo evaporation at room temperature to remove the solvent. The obtained slurry was later dissolved with water.

\section{Source of, and Extraction of Nematode Juveniles}

Galled roots of Celosia argenteawere sourced from a farm at Oyun area of Ilorin town. The galled roots were washed gently with water to remove sands and plant debris that stuck to them. They were then chopped into bits and macerated in the warning blender for duration of three minutes and later removed into the extraction tray to allow the nematode to migrate into the water for duration 24 hours. The juvenile suspension on the 
extraction trey was decanted into bucket and allowed to stand so as to drain excess water. The remaining juvenile suspension was sampled for the presence of nematode juvenile under stereomicroscope. The juvenile suspension was standardized to contain 7 juveniles per $\mathrm{ml}$ of the juvenile water.

\section{INOCULATION}

After 14 days of transplanting, 25 of the experimental pots were inoculated each with 210 juvenile of Meloidogynespp by pouring $30 \mathrm{ml}$ of the extracted juvenile suspension into $1 \mathrm{~cm}$ hole around the base of the seedling, and filling the holes with moist soil. The remaining 25 pots were not inoculated with nematodes.

\section{APPLiCATION OF TREATMENTS}

Seven days after inoculation, the inoculated and non-inoculated plants were differently treated with the various test leaf extracts, powder and carbofuran.

The test plant powder was applied as soil amendment and incorporated into the soil at the rate of $25 \mathrm{~g} / \mathrm{pot}$ which is equivalent to 5 tons/ha while the test plant liquid extracts were applied to the soil at the rate of $210 \mathrm{ml}$ per pot. Also, the test plant ethanolic extracts were applied to the soil at the rate of $210 \mathrm{ml}$ per pot. The synthetic nematicide, carbofuran was applied at the rate of $0.5 \mathrm{~g} / \mathrm{stand}$ which is equivalent to $3 \mathrm{~kg}$ ai $/ \mathrm{ha}$. There was an untreated control. Each treatment was replicated 5 times. Thus the experiment was a $5 \times 2 \times 5$ factorial experiment.

\section{Data Collection}

Data on the following parameters were collected from the planted sweet pepper: plant height and number of leaves at weekly intervals, number of branches, days to $50 \%$ flowering, shoot weight, root gall indices.

Fruit weight was also taken at plant maturity.

The scale used for the rating /the roots for galling (Taylor and Sasser, 1938) is shown below:

$0=$ No infection

$1=1-5 \%$ of the roots galled

$2=6-25 \%$ of the roots galled

$3=26-50 \%$ of the roots galled

$4=51-75 \%$ of the roots galled

$5=76-100 \%$ of the roots galled

\section{Data Analysis}

All data collection from the experiment was subjected to analysis of variance (ANOVA) using SPSS statistical package.

\section{RESULTS}

\section{Plant Height}

Table 1 shows the effects of nematode inoculation and application of extracts of Jatrophacurcasand carbofuran on the plant height of sweet pepper (Capsicum annum). There were significant differences in the height of nematode inoculated plant and uninoculated plant right from the $4^{\text {th }}$ week after planting (WAP) to the termination of the experiment at $12^{\text {th }}$ WAP. The sweet pepper plants that were not inoculated with root-knot nematode juveniles were significantly taller than their inoculated counter parts. 
American Research Journal of Agriculture (ARJA)

Table 1. The effect of root knot nematode inoculation and treatment with carbofuranand Jatrophacurcas on the plant height of sweet pepper

\begin{tabular}{|l|l|l|l|l|l|l|l|l|l|}
\hline \multirow{2}{*}{$\begin{array}{l}\text { Treatment } \\
\text { nematode }\end{array}$} & \multicolumn{9}{|c|}{ Means of plant height (cm) } \\
\cline { 2 - 10 } & $\mathbf{4}$ WAP & $\mathbf{5 ~ W A P}$ & $\mathbf{6}$ WAP & $\mathbf{7 ~ W A P}$ & $\mathbf{8}$ WAP & $\mathbf{9}$ WAP & $\begin{array}{c}\mathbf{1 0} \\
\text { WAP }\end{array}$ & $\begin{array}{c}\mathbf{1 1} \\
\text { WAP }\end{array}$ & $\mathbf{1 2}$ WAP \\
\hline Inoculation & $19.55^{\mathrm{d}}$ & $21.70^{\mathrm{d}}$ & $23.98^{\mathrm{d}}$ & $27.74^{\mathrm{d}}$ & $33.40^{\mathrm{d}}$ & $38.49^{\mathrm{d}}$ & $44.18^{\mathrm{d}}$ & $46.38^{\mathrm{d}}$ & $46.85^{\mathrm{d}}$ \\
\hline No Inoculation & $20.38^{\mathrm{a}}$ & $23.47^{\mathrm{a}}$ & $25.91^{\mathrm{a}}$ & $29.81^{\mathrm{a}}$ & $34.55^{\mathrm{a}}$ & $40.32^{\mathrm{a}}$ & $45.20^{\mathrm{a}}$ & $48.12^{\mathrm{a}}$ & $50.06^{\mathrm{a}}$ \\
\hline S.E.D & 0.349 & 0.364 & 0.302 & 0.367 & 0.278 & 0.1091 & 0.203 & 0.143 & 0.470 \\
\hline $\begin{array}{l}\text { EXTRACTS } \\
\begin{array}{l}\text { Aqueous of Jat- } \\
\text { rophacurcas }\end{array}\end{array}$ & $19.58^{\mathrm{b}}$ & $22.25^{\mathrm{b}}$ & $25.09^{\mathrm{ab}}$ & $28.77^{\mathrm{bc}}$ & $33.86^{\mathrm{ab}}$ & $38.74^{\mathrm{b}}$ & $44.10^{\mathrm{a}}$ & $47.06^{\mathrm{a}}$ & $48.02^{\mathrm{a}}$ \\
\hline $\begin{array}{l}\text { Ethanoic extract } \\
\text { of Jatrophacur- } \\
\text { cas }\end{array}$ & $21.28^{\mathrm{a}}$ & $23.42^{\mathrm{b}}$ & $25.37^{\mathrm{ab}}$ & $28.99^{\mathrm{b}}$ & $34.21^{\mathrm{ab}}$ & $40.43^{\mathrm{a}}$ & $45.70^{\mathrm{a}}$ & $47.84^{\mathrm{a}}$ & $48.19^{\mathrm{a}}$ \\
\hline $\begin{array}{l}\text { Powder of Jat- } \\
\text { rophacurcas }\end{array}$ & $19.27 \mathrm{~b}$ & $20.14 \mathrm{~b}$ & $23.85 \mathrm{bc}$ & $26.95 \mathrm{c}$ & $33.39^{\mathrm{ab}}$ & $38.72^{\mathrm{b}}$ & $43.20^{\mathrm{a}}$ & $46.50^{\mathrm{a}}$ & $47.92^{\mathrm{ab}}$ \\
\hline Carbofuran & $21.97^{\mathrm{b}}$ & $25.32^{\mathrm{b}}$ & $27.73^{\mathrm{a}}$ & $32.00^{\mathrm{a}}$ & $36.29^{\mathrm{a}}$ & $41.50^{\mathrm{a}}$ & $45.81^{\mathrm{a}}$ & $47.93^{\mathrm{a}}$ & $49.59^{\mathrm{a}}$ \\
\hline Control & $17.74^{\mathrm{b}}$ & $20.14^{\mathrm{b}}$ & $22.70^{\mathrm{c}}$ & $26.95^{\mathrm{c}}$ & $32.12^{\mathrm{b}}$ & $37.65^{\mathrm{b}}$ & $40.02^{\mathrm{b}}$ & $43.50^{\mathrm{b}}$ & $46.03^{\mathrm{b}}$ \\
\hline S.E.D. & 1.831 & 1.797 & 1.775 & 1.696 & 1.459 & 1.341 & 1.111 & 0.968 & 0.470 \\
\hline
\end{tabular}

Mean while the same alphabet( $S$ ) in the same column are not significantly different at $P=0.05$ according to Duncan's Multiple Range Test

There was significant difference between treatment forms. At the $5^{\text {th }}$ WAP to 12 WAP, generally carbofuran treated plants were significantly higher than those treated with aqueous extract, ethanolic extract and powder of Jatrophacurcas. There were no significantly differences in the height of plants treated with aqueous extracts of Jatrophacurcas. There was no significantly difference in the height of plants treated with aqueous exatracts of Jatrophacurcas. However, they were significantly taller than the plants treated with the powder of the test plants performed significantly than the control trials

\section{Number of Leaves}

Table 2 shows that there were significant differences in the effect of nematode inoculation on the number of leaves per plant of sweet pepper. All through the period of observation, from the $4^{\text {th }}$ week to the $12^{\text {th }}$ week, plants which were not inoculated with nematode, Moloidogne incognita produced significantly higher number of leaves per plant than the nematode inculated ones.

Table 2. The effect of root knot nematode inoculation and treatment with carbofuranandJatrophacurcas on the number of leaves of sweet pepper (Capsicum annuum)

\begin{tabular}{|l|l|l|l|l|l|l|l|l|l|}
\hline \multirow{2}{*}{$\begin{array}{c}\text { Treatment } \\
\text { nematode }\end{array}$} & \multicolumn{8}{|c|}{ Means of plant height (cm) } \\
\cline { 2 - 11 } & 4 WAP & 5 WAP & 6 WAP & 7 WAP & 8 WAP & 9 WAP & 10 WAP & 11 WAP & 12 WAP \\
\hline Inoculation & $16.96^{\mathrm{D}}$ & $19.92^{\mathrm{D}}$ & $22.48^{\mathrm{D}}$ & $27.64^{\mathrm{D}}$ & $33.40^{\mathrm{D}}$ & $40.04^{\mathrm{D}}$ & $45.66^{\mathrm{D}}$ & $50.04^{\mathrm{D}}$ & $51.00^{\mathrm{D}}$ \\
\hline No Inoculation & $19.06^{\mathrm{a}}$ & $22.12^{\mathrm{a}}$ & $24.72^{\mathrm{a}}$ & $29.00^{\mathrm{a}}$ & $35.28^{\mathrm{a}}$ & $42.40^{\mathrm{a}}$ & $48.56^{\mathrm{a}}$ & $53.12^{\mathrm{a}}$ & $54.40^{\mathrm{a}}$ \\
\hline S.E.D & 0.781 & 0.447 & 0.542 & 0.264 & 0.194 & 0.584 & 0.540 & 0.878 & 0.660 \\
\hline
\end{tabular}

Volume 2

Page 5 
American Research Journal of Agriculture (ARJA)

\begin{tabular}{|l|l|l|l|l|l|l|l|l|l|}
\hline $\begin{array}{l}\text { EXTRACTS Aque- } \\
\text { ous of Jatro- } \\
\text { phacurcas }\end{array}$ & 17.80 & $20.90^{\mathrm{ab}}$ & $23.20^{\mathrm{b}}$ & $28.10^{\mathrm{bc}}$ & $34.20^{\mathrm{b}}$ & $40.01^{\mathrm{b}}$ & $45.80^{\mathrm{b}}$ & $49.50^{\mathrm{b}}$ & $52.70^{\mathrm{b}}$ \\
\hline $\begin{array}{l}\text { Ethanoic extract } \\
\text { of Jatrophacurcas }\end{array}$ & $18.60^{\mathrm{ab}}$ & $21.70^{\mathrm{a}}$ & $24.10^{\mathrm{ab}}$ & $28.90^{\mathrm{ab}}$ & $35.10^{\mathrm{ab}}$ & $40.50^{\mathrm{b}}$ & $46.70^{\mathrm{b}}$ & $51.20^{\mathrm{b}}$ & $54.28^{\mathrm{ab}}$ \\
\hline $\begin{array}{l}\text { Powder of Jatro- } \\
\text { phacurcas }\end{array}$ & $17.40 \mathrm{~b}$ & $20.40 \mathrm{ab}$ & $23.01^{\mathrm{b}}$ & $27.50^{\mathrm{a}}$ & $33.50^{\mathrm{b}}$ & $38.40^{\mathrm{bc}}$ & $44.80^{\mathrm{b}}$ & $48.20^{\mathrm{bc}}$ & $51.90^{\mathrm{ab}}$ \\
\hline Carbofuran & $20.20 \mathrm{a}$ & $23.20^{\mathrm{a}}$ & $26.20^{\mathrm{a}}$ & $30.50^{\mathrm{a}}$ & $37.00^{\mathrm{a}}$ & $43.60^{\mathrm{a}}$ & $49.00^{\mathrm{a}}$ & $54.80^{\mathrm{a}}$ & $57.90^{\mathrm{a}}$ \\
\hline Control & $16.10^{\mathrm{b}}$ & $18.90^{\mathrm{b}}$ & $21.30^{\mathrm{b}}$ & $26.60^{\mathrm{c}}$ & $30.00^{\mathrm{b}}$ & $35.70^{\mathrm{b}}$ & $40.15^{\mathrm{b}}$ & $46.70^{\mathrm{bc}}$ & $50.21^{\mathrm{c}}$ \\
\hline S.E.D. & 0.926 & 0.943 & 0.867 & 0.734 & 0.395 & 0.414 & 0.697 & 0.745 & 0.766 \\
\hline
\end{tabular}

Mean while the same alphabet(s) in the same column are not significantly different at $P=0.05$ according to Duncan's Multiple Range Test

It was also observed that there were significant differences among treatments on number of leaves per plant. Carbofuran treated plants produced the highest number of leaves. There were no significant difference among the other treatments, aqueous, ethanoic extract and powder of Jatrophacurcas. But these were significantly better than the control. The control trials recorded the least number of leaves.

\section{Number of Branches}

Table 3 shows the main effect of inoculation, carbofuran and plant extract of Jatrophacurcas on the number of branches of the treated plant from the $5^{\text {th }}-12^{\text {th }}$ WAP. There was a significant increase in the number of branches of the uninoculated plant as compared to the nematode inoculated plants.

Table 3. The effect of root knot nematode inoculation and treatment with carbofuranandJatrophacurcas on the number of branches per plant of sweet pepper (Capsicum annuum)

\begin{tabular}{|c|c|c|c|c|c|c|c|c|}
\hline \multirow{2}{*}{$\begin{array}{l}\text { Treatment } \\
\text { nematode }\end{array}$} & \multicolumn{8}{|c|}{ Means of plant height (cm) } \\
\hline & 5 WAP & 6 WAP & 7 WAP & 8 WAP & 9 WAP & 10 WAP & 11 WAP & 12 WAP \\
\hline Inoculation & $1.24^{\mathrm{D}}$ & $2.36^{\mathrm{D}}$ & $3.56^{\mathrm{D}}$ & $4.20^{\mathrm{D}}$ & $5.16^{\mathrm{D}}$ & $5.72^{\mathrm{D}}$ & $6.12^{\mathrm{D}}$ & $6.64^{\mathrm{D}}$ \\
\hline No Inoculation & $1.76^{\mathrm{a}}$ & $2.88^{\mathrm{a}}$ & $3.64^{\mathrm{a}}$ & $5.12^{\mathrm{a}}$ & $5.64^{\mathrm{a}}$ & $5.92^{\mathrm{a}}$ & $6.28^{\mathrm{a}}$ & $6.80^{\mathrm{a}}$ \\
\hline S.E.D & 0.162 & 0.150 & 0.102 & 0.102 & 0.215 & 0.179 & 0.233 & 0.160 \\
\hline $\begin{array}{l}\text { EXTRACTS } \\
\text { Aqueous of Jat- } \\
\text { rophacurcas }\end{array}$ & $1.50^{\mathrm{ab}}$ & $2.60^{\mathrm{ab}}$ & $3.60^{\mathrm{ab}}$ & $4.40^{\mathrm{ab}}$ & $5.70^{\mathrm{a}}$ & $6.40^{\mathrm{a}}$ & $7.50^{\mathrm{a}}$ & $7.90^{\mathrm{a}}$ \\
\hline $\begin{array}{l}\text { Ethanoic extract } \\
\text { of Jatrophacur- } \\
\text { cas }\end{array}$ & $1.80^{\mathrm{ab}}$ & $2.80^{\mathrm{ab}}$ & $3.80^{\mathrm{ab}}$ & $4.60^{\mathrm{b}}$ & $5.90^{\mathrm{a}}$ & $6.60^{\mathrm{a}}$ & $7.80^{\mathrm{a}}$ & $8.00^{\mathrm{a}}$ \\
\hline $\begin{array}{l}\text { Powder of Jat- } \\
\text { rophacurcas }\end{array}$ & $1.10^{\mathrm{ab}}$ & $2.30^{\mathrm{ab}}$ & $3.10^{\mathrm{ab}}$ & $4.10^{\mathrm{a}}$ & $5.50^{\mathrm{a}}$ & $6.10^{\mathrm{a}}$ & $7.30^{\mathrm{a}}$ & $7.70^{\mathrm{a}}$ \\
\hline Carbofuran & $2.20^{\mathrm{a}}$ & $3.40^{\mathrm{a}}$ & $4.80^{\mathrm{a}}$ & $5.70^{\mathrm{a}}$ & $6.80^{\mathrm{a}}$ & $7.80^{\mathrm{a}}$ & $8.90^{\mathrm{a}}$ & $9.80^{\mathrm{a}}$ \\
\hline Control & $0.90^{\mathrm{b}}$ & $1.60^{\mathrm{b}}$ & $2.40^{\mathrm{b}}$ & $2.90^{\mathrm{b}}$ & $3.50^{\mathrm{b}}$ & $4.90^{\mathrm{b}}$ & $5.70^{\mathrm{b}}$ & $6.20^{\mathrm{b}}$ \\
\hline S.E.D. & 0.72 & 0714 & 0539 & 0.401 & 0.313 & 0.335 & 0.367 & 0.386 \\
\hline
\end{tabular}

Mean while the same alphabet(s) in the same column are not significantly different at $P=0.05$ according to Duncan's Multiple Range Test

Volume 2 
The result further showed that there were significant differences between treated and untreated plants (control) on the number of branches. There were no significant differences in number of branches produced by plant treated with the plant extracts and the synthetic nematicide, carbofuran. The control plants produced the least number of branches.

\section{Days to $50 \%$ Flowering}

The effect of nematode inoculation was significant on the day $50 \%$ flowering. The inoculated plants did not flower in time, while the uninoculated sweet pepper plants flowered early than the inoculated ones as shown in Table 4, the result further showed the main effects of carbofuran and plant extract of Jatrophacurcas on days to $50 \%$ flowering. There were no significant differences in days to $50 \%$ flowering among sweet pepper treated with carbofuran, ethanoic and aqueous extract of Jatrophacurcas. Cabofuran gave a significantly better result than the powder of Jatrophacurcas and the control plants. There was no significant difference between extracts of Jatropha and the control trails on the days to $50 \%$ flowering.

\section{Shoot Weight}

The main effect of nematode inoculated was significant on shoot weight as the shoot of the uninoculated sweet pepper plants was significantly higher than the of the inoculated plant as shown in table 4 Results in Table 4 further show the main effect of carbofuran plant extracts of Jarophacurcas used on the shoot weight of treated sweet pepper. The result shows that there were significant differences in shoot weight among the treatments used. Carbofuran and ethanolic extract treated plants produced the highest shoot weight than the other treatments. The control plants recorded the least shoot weight.

Table 4. The effect of root knot nematode inoculation and treatment with carbofuran and Jatrophacurcas on days to $50 \%$ flowering, shoot weight, root weight, fruit weight and number of fruit of sweet pepper (Capsicumannuum)

\begin{tabular}{|l|l|l|l|l|l|}
\hline \multicolumn{1}{|c|}{$\begin{array}{c}\text { TREATMENT } \\
\text { NEMATODE }\end{array}$} & $\begin{array}{c}\text { DAYS TO 50\% } \\
\text { FLOWERING }\end{array}$ & $\begin{array}{c}\text { SHOOT } \\
\text { WEIGHT (g) }\end{array}$ & $\begin{array}{c}\text { ROOT WEIGHT } \\
\text { (g) }\end{array}$ & $\begin{array}{c}\text { FRUITS } \\
\text { WEIGHT (g) }\end{array}$ & $\begin{array}{c}\text { NUMBER OF } \\
\text { FRUIT/POT }\end{array}$ \\
\cline { 2 - 6 } Inoculation & $91.72^{\mathrm{b}}$ & $10.82^{\mathrm{b}}$ & $6.97^{\mathrm{b}}$ & $2.82^{\mathrm{b}}$ & $1.12^{\mathrm{b}}$ \\
\hline No Inoculation & $77.84^{\mathrm{a}}$ & $14.38^{\mathrm{a}}$ & $7.91^{\mathrm{a}}$ & $6.04^{\mathrm{a}}$ & $3.48_{\mathrm{a}}$ \\
\hline S.E.D & 1.873 & 0.991 & 1.650 & 1.364 & 0.542 \\
\hline $\begin{array}{l}\text { EXTRACTS } \\
\text { Aqueous of Jatro- } \\
\text { phacurcas }\end{array}$ & $85.30^{\mathrm{ab}}$ & $11.50^{\mathrm{ab}}$ & $8.60^{\mathrm{a}}$ & $4.43^{\mathrm{ab}}$ & $1.97^{\mathrm{ab}}$ \\
\hline $\begin{array}{l}\text { Ethanoic extract } \\
\text { of Jatrophacurcas }\end{array}$ & $85.70^{\mathrm{ab}}$ & $13.66^{\mathrm{a}}$ & $8.69^{\mathrm{a}}$ & $4.73^{\mathrm{ab}}$ & $2.00 \mathrm{a}^{\mathrm{b}}$ \\
\hline $\begin{array}{l}\text { Powder of Jatro- } \\
\text { phacurcas }\end{array}$ & $87.90^{\mathrm{b}}$ & $11.31^{\mathrm{ab}}$ & $5.97^{\mathrm{b}}$ & $3.36^{\mathrm{b}}$ & $1.92^{\mathrm{ab}}$ \\
\hline Carbofuran & $80.83^{\mathrm{a}}$ & $15.58^{\mathrm{a}}$ & $9.58^{\mathrm{a}}$ & $5.14^{\mathrm{a}}$ & $3.30^{\mathrm{a}}$ \\
\hline Control & $90.00^{\mathrm{b}}$ & $10.82^{\mathrm{b}}$ & $4.87^{\mathrm{b}}$ & $2.00^{\mathrm{b}}$ & $1.00^{\mathrm{b}}$ \\
\hline S.E.D. & 1.224 & 1.439 & 1.752 & 1.731 & 0.798 \\
\hline
\end{tabular}

Mean while the same alphabet(s) in the same column are not significantly different at $P=0.05$ according to Duncan's Multiple Range Test 


\section{Root Weight}

In table 4, nematode inoculated had significant effect as the inoculated plants had reduced root weight.

The treatments also had a significant effect on root weight. The sweet peeper plants which were treated with carbofuran, aqueous and ethanoic plant extracts had a significantly higher root weight than the powder treated and control plants.

\section{Fruit Weight}

Table 4 shows the result on the effect of nematode inoculation, carbofuran and plant extracts ofJatrophacurcason the fruit weight at 12 WAP. There was a significant increase in the fruit weight of the inoculated plants as opposed to the inoculated plants. The table further shows that fruit weight was generally higher when the plant was treated with carbofuran. Though there was no significant difference between the plant extracts and carbofuran, the plants treated with Jatrophacurcaspowder using the control plant gave the least fruit weight.

\section{Number of Fruits/Pot}

There were significant differences in the effect of nematode inoculation on the number of fruits / pot. The uninoculatedplants produced significantly higher number of leaves than the inoculated plants (Table 4). Number of fruits / pot was significantly higher in the carbofuran treated plant than the control plants while the number of fruits / pot did not differ significantly in the other treatment as well as the control, though recorded the least number of fruits/pot.

\section{Root Gall Rating}

Table 5 shows that nematode inoculation resulted in root galling and was significantly different from uninoculated plants which had no galls. The table further shows the main effect of carbofuran and plants extracts of Jatrophacurcason root galling index of the treated plant at 12 WAP. There were significant differences between treated and control trials in terms of root galling. Treated plants performed significantly better than the control plants, but there was no significant difference among treatments.

Table 5. The main effect of root knot nematodes inoculation and treatment with carbofuran and Jatrophacurcas on root galling index of sweet pepper (Capsicumannum) at 12 WAP

\begin{tabular}{|l|c|}
\hline \multicolumn{1}{|c|}{ TREATMENTS NEMATODE } & MEAN ROOT GALLING INDEX \\
\hline Inoculation & $2.71^{\mathrm{b}}$ \\
No Inoculation & $0.00^{\mathrm{a}}$ \\
EXTRACTS & \\
\hline Aqueous of Jatrophacurcas & $0.90^{\mathrm{a}}$ \\
Ethanoic extract of Jatrophacurcas & $0.80^{\mathrm{a}}$ \\
Powder ofJatrophacurcas & $1.80^{\mathrm{a}}$ \\
Carbofuran & $0.60^{\mathrm{a}}$ \\
Control & $3.70^{\mathrm{b}}$ \\
S.E.D. & 0.379 \\
\hline
\end{tabular}

Mean with the same alphabet(s) in the same column are not significantlydifferent at $p=0.05$ according to Duncan's Multiple Range Test. 
Table 6 shows the detectability or otherwise by chemical analysis of carbohydrates, reducing compound terpenoids, steroid, alkaloid, tannis/polyphenols, flavaonoids, antroguniones, reducing sugar and saponins contents in Jatrophacurcas the result show that the plant material contained carbohydrate, steroid and saponin to different extent.

Table 6. Active organic chemical ingredient detected injatrophacurcas

\begin{tabular}{|l|c|}
\hline Chemical ingredient tested for & Presence or absence of the ingredient \\
\hline Carbohydrate & + \\
Reducing Compound Terpenoids & - \\
Steriod & + \\
Alkaloid & - \\
Tannis/polyphenols & - \\
Flavaonoids & - \\
Antroguniones, & - \\
Reducing sugar & - \\
Saponins & + \\
\hline
\end{tabular}

Key: + = Chemical ingredient detected, - = Chemical ingredient not detected

\section{DiSCUSSION AND RECOMMENDATION}

\section{Discussion}

According to Oladokunet al. (1987), growth can be evaluated by measuring certain vegetative characters of the plant. These include shoot length or plant height, number of leaves, number of branches, days to $50 \%$ plant flowering, number of fruits, shoot weight and less root galling index. Data collection in this study followed this principle.

The results of the experiment indicated that there were significant differences between nematode inoculated plant and uninoculated plant. Root knot nematodes caused considerable reduction in growth and yield of the test plant (sweet pepper,Capsicum annnum). This is observed in the differences in growth and yield between the treated plants and the untreated (i.e. control) plants. This kind of observation is not an uncommon phenomenon in nematode plant interaction. Bhatti and Jain (1977) reported a yield loss of up to $91 \%$ from nematode infection of brinjal while Babatola (1990) reported 90\% loss in fruit weight in untreated okra infected by Meloidogyne incognita.

The severity of infection and yield loss observed in the study as reflected in the height, number of leaves and number of branches of tested sweet pepper (Capsicum annnum) were observed to reduce with increasing application of treatments (i.e. carbofuran, ethanoic, aqueous extract and powder of Jatrophacurcasthat were evaluated for their nematicidal activities. Besides shoot weight and root weight were significantly increased in plants treated with carbofuran and the plant extracts of Jatrophacurcas compared to the untreated (control) plants.

It was observed that leaf number increment was proportional to increase in both plant height and number of branches in treated plants than in untreated ones. This could be inferred from the fact that such plants were less attacked by nematodes. As a result, more nutrient were available in their system to carry out the normal physiological functions including leaf development, photosynthesis, replacement and regeneration of new tissues resulting in growth and development of new branches. 
It could also be drawn from the fact that apart from the nematicidal properties of the plant material, the plants for the extracts also added to the soil nutrients, which were used by the plants for the better growth and yield. This is an agreement with the report of Thomson (1987)Olabiyi(1990), Fatokiand Oyedunmade (1996) who reported early flowering in treated plants, late flowering was observed in untreated sweet pepper plants in this study. Physiologically, this might be a result of induced aging imposed on the plants metabolic and reproductive system as could be found in any living organism consistent and persistent stress in the tissues.

On the other hand, it is economically rewarding since the treated plants will produce leaves of larger area and number for a long time before diverting its physiological processes to reproduction, which will lead to fewer leaves and more fruits. The fewer number of fruits in the untreated plants was also as a result of flower abortion and premature fruit fall. Stunted growth, reduced number of leaves and flower abortion, root galling and reduced yield are well known symptoms of root knot nematode infection as also noted long ago by and Tayo (1980).

Treated plants were significantly less galled than the control as observed in this study. In the soil system, the concentrations of carbofuran and plants material used against root knot nematodes are expected to maintain their action for several days. Thus, longer exposure to the treatments in soil might have contributed to grater juvenile mortality. The cumulative effects on the plants were less vigor and vitality, which resulted in their oval poor growth and yield.

The bioactive compounds present in the test plant, vis - a - vis, tannin, saponin, falvonoids, alkaloids anthraquione could have been the reason for the efficacy of Jatrophacurcas in controlling root knot nematode affecting sweet pepper, this is in agreement with the report of Deverall (1972) on the pesticidal astringency and phytorepellant nature of flavonoids and other bioactive compounds present in plants.

\section{RECOMMENDATIONS}

Nematodes are among the agents that caused low yield and heavy crop losses in agricultural field, but farmers could find solace in the use of organic materials as an alternative to the very expensive synthetic nematicide as it has been demonstrated in this study.

Nematotoxic plants materials are friendly to the environment, they do not leave behind toxic metabolic like the synthetic chemical, most especially the organochlorides, and in most cases, they are of medicinal value to man, and are cheap and easy to apply.

From the result of pots experiment and the invitro assessment of the toxicity of Jatrophacurcas to juvenile of Meloidogyne species it was observed that the aqueous extracts ethnolic extract and powder from Jatrophacurcas at $210 \mathrm{ml} / 25 \mathrm{~g}$ of application is more effective than the powder form. It was also observed that the aqueous extract of Jatrophacurcaswas also more effective than the powder form, thus the use of plants extracts instead of prohibitive synthetic chemicals to control root knot nematode holds promises for the future.

The ready availability of Jatrophacurcas ${ }_{\mathbf{L}}$ and it effects on nematode population, and plant growth suggest the need for additional studies in the field to evaluate the efficacy and economics of its use for root knot nematode management.

\section{REFERENCES}

1. Allardice P. (1993). A-Z of companion of planting. Cassel publishers ltd.

2. Babatola, J.O. (1990) Pathogenicacity of root knot nematode M. incognita on okra Abelmosechus esculent and pest of Okra. Nigeria Journal of Plant Protection 13:23 - 29

3. Bhatti, D. S. and J. K. Jain (1977). Estimation of losses in Okra, tomato and brinja yield due to M.incognita,IndianJournal of Nematology 7. (1) 37 - 41 
4. Chiej R. (1984) Encyclopedia of Medicinal Plants.

5. Dalziel, J.M. (1948). The useful plants of West Africa.Crown agents for over seas Government London. Pp. 24-27

6. Deverall, B.J. (1972). In Phytochemical Ecology, ed. Harnborne, J.B. Academic press. London. Pp. 217-234

7. FAO. (1984). Production year book Vol. 34. Pp. 154, F.A.O UN.Rome Italy.

8. Fatoki O.K and E.E.A Oyedunamde (1996) controlling effect of some plant leaves on the root nematode Meloidogyne incognita attacking tomato, Lycopersicon esculentum. Mill Niger. J. Plt Prot. 16, 59-65

9. Heiger, D. N. and Smith, L. M. (1973). The cultivated capsicum pepper Crop Bot. pp. 214-227.

10. Hill D.S. and T.M. Walter. (1988) Pests and diseases of tropical crops, Vol. 2 Field handbook. Longman group ltd. Pg. 30

11. Howard, R. J., J. A. Garland and W. L. Seaman. 1994. Diseases and pests of vegetable crops in Canada. The Canadian Phytopathological Society and the Entomological Society of Canada.

12. Grubben, C.J. (1977) Amaranthus in tropical vegetables and their genetic resources H.D. Tindall and J.T William (E.D.S.). Pg. 96-101.

13. Nath R.P. and U.S. Singh (1992) effect of root know disease on papaya cultivation. National seminar of production and utilization papaya. March 607, 1992. Tamil BahuAgric University Cambatore., India, 9.63

14. Oke, O.L. (1966). Chemistry studies on the more commonly used leaf vegetables in Nigeria West African Science Area 11:42-48.

15. Olabiyi, T.I. (1990) the role of crop residues in the control nematode pest of cowpea.B.Agric thesis: Dept. of crop protection, University of Ilorin, PP 78.

16. Oladokun, M., A.O. Okelana and E.B. Esan (1987) Effects of plant population density on growth and yield of four tea(Camellia sinensis L) clones on mambila plateau. Nig. J. Argron 2 (1): 1-4

17. Omueti O. (1980) effect of geo celosia cultivar,Expl. Agric 16:179-286

18. Oyenuga, V.A. and Fetuga (1997) Dietary importance of fruits and vegetable. Proceedings of First National Seminar and Fruits and Vegetables, NIHORT Ibadan.

19. Thomson I. J. (1987) Challenge facing nematology: environmental risk with nematicidies and the need for new approaches. Pp. 469 - 476. In vesta on nematology (Veech J. A. and 24. D. W. Dickson) E. O. Painter Printing Co. Florida U.S.A.

Citation: Hinmikaiye, A.S., 1Abolusoro, S.A., Oloniruha, J.A., Ogundare, S.K.,Babalola, T.S.,Kadiri, W.O.J, Ayodele, F.G, "Studies on the Comparative Toxicity of Jatrophacurcas and Synthetic Nematicide on the Root-Knot Nematode Infected Sweet Pepper (Capsicum Annuum)". American Research Journal of Agriculture, Volume 2; pp:1-11

Copyright (C) 2016 Hinmikaiye, A.S., 1Abolusoro, S.A.,Oloniruha, J.A., * Ogundare, S.K.,Babalola, T.S.,Kadiri, W.O.J, Ayodele, F.G, This is an open access article distributed under the Creative Commons Attribution License, which permits unrestricted use, distribution, and reproduction in any medium, provided the original work is properly cited. 